\title{
(-)-Epigallocatechin-3-gallate inhibits bladder cancer stem cells via suppression of sonic hedgehog pathway
}

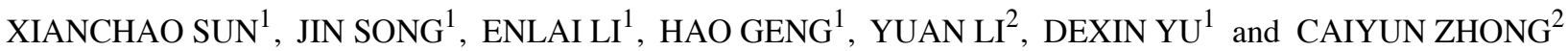 \\ ${ }^{1}$ Department of Urology, The Second Affiliated Hospital of Anhui Medical University, Hefei, Anhui 230032; \\ ${ }^{2}$ Department of Nutrition and Food Safety, Center for Global Health, School of Public Health, \\ Nanjing Medical University, Nanjing, Jiangsu 211166, P.R. China
}

Received September 21, 2018; Accepted May 20, 2019

DOI: $10.3892 /$ or.2019.7170

\begin{abstract}
Cancer stem cells (CSCs) are associated with the occurrence and metastasis of human malignant tumors, and targeting CSCs is an important strategy for cancer prevention and overcoming drug resistance. (-)-Epigallocatechin-3-gall ate (EGCG), a bioactive polyphenol from green tea, has been studied extensively for its beneficial effects on various tumors including bladder cancer. However, the mechanism underlying the effect of EGCG on bladder CSCs remains poorly understood. Here, the authors investigated the expression of bladder CSCs markers including cluster of differentiation (CD)44, CD133, Oct4, ALDH1A1 and Nanog, and their role in the effect of EGCG on bladder CSCs. EGCG inhibited bladder cancer tumorspheres, downregulated stem cell markers, suppressed the expression of proliferation-associated proteins in and promoted the apoptosis of bladder CSCs. The effect of EGCG was mediated by the sonic hedgehog signaling pathway, and upregulation of sonic hedgehog signaling pathway components attenuated the suppressive effects of EGCG. Taken together, the results indicated that EGCG could be an important natural compound against bladder CSCs and provide new insights into the effective molecular targeting of bladder CSCs.
\end{abstract}

\section{Introduction}

Bladder cancer is a common urinary cancer worldwide and its high rate of recurrence results in poor clinical outcomes (1).

Correspondence to: Professor Dexin Yu, Department of Urology, The Second Affiliated Hospital of Anhui Medical University, 80 Feicui Road, Hefei, Anhui 230032, P.R. China

E-mail: ay2fy_uro@126.com

Professor Caiyun Zhong, Department of Nutrition and Food Safety, Center for Global Health, School of Public Health, Nanjing Medical University, 818 East Tianyuan Road, Nanjing, Jiangsu 211166, P.R. China

E-mail: cyzhong@njmu.edu.cn

Key words: bladder cancer stem cells, (-)-epigallocatechin-3-gallate, sonic hedgehog signaling pathway, inhibition
Patients with high-risk bladder tumors have approximately a $50 \%$ chance of recurrence if treated with surgery alone (2). The American Cancer Society estimates approximately 81,190 new cases and 17,240 deaths from bladder cancer in 2018 (3). There are two major phenotypes in bladder cancer: Muscle-invasive bladder cancer and non-muscle-invasive bladder cancer (4). After surgical resection, the current standard treatment is cisplatin-based chemotherapy (5).

Cancer stem cells (CSCs), which are found in various solid cancers, including bladder cancer, comprise a small population of tumor cells, which play indispensable roles in cancer development and metastasis $(6,7)$. CSCs are characterized by a slow growth rate and high expression levels of drug efflux proteins including ATP-binding cassette transporters (8). CSCs have significant clinical implications because they have been correlated with chemoresistance (9). Bladder CSCs were first identified in 2009 and the existence of bladder CSCs contributes to the resistance to anticancer therapeutics (10). The sonic hedgehog protein (Shh) signaling pathway plays an important role in the maintenance of CSCs and mediates tumorigenesis in many cancers (11). Shh proteins bind to and inactivate the 12-pass transmembrane protein protein patched homolog 1 (Ptch1), which inhibits the seven-pass transmembrane protein smoothened homolog (Smo) (12). The release of Smo leads to the activation of zinc finger protein GLI (Gli) family transcription factors, which induce the transcription of target genes (12). The Shh signaling pathway is critical for the development, initiation and progression of bladder cancer, and promotes bladder tumorigenicity and stemness by activating epithelial-to-mesenchymal transition (13). Shh signaling pathway activity shows distinct spatial and temporal distribution during bladder development (13).

(-)-Epigallocatechin-3-gallate (EGCG) is an abundant polyphenol from green tea and plays antitumor roles in various cancers including bladder cancer (14). EGCG downregulates nuclear factor- $\kappa \mathrm{B}$ and matrix metalloproteinase- 9 to inhibit bladder cancer SW780 cell proliferation and migration both in vitro and in vivo (15). In addition, EGCG also suppresses bladder cancer cell metastasis via the PI3K/AKT signaling pathway (16). Furthermore, EGCG was shown to inhibit lung and colorectal CSCs by affecting the Wnt/ $\beta$-catenin signaling pathway, and EGCG downregulates STAT3 to suppress the stem-cell-like characteristics of nasopharyngeal cancer (17-19). 
Moreover, EGCG significantly reduces recurrence in patients with colorectal adenoma, and acts synergistically with cisplatin and oxaliplatin via the autophagy pathway in human colorectal cancer cells (20). However, the molecular mechanisms underlying the effect of EGCG on bladder CSCs remain unknown. In the present study, the authors investigated the effect of EGCG on bladder CSCs.

\section{Materials and methods}

Cell culture and reagents. Human bladder cancer cell lines EJ and UM-UC-3 were obtained from American Type Culture Collection and maintained at $37^{\circ} \mathrm{C}$ in incubator containing $5 \% \mathrm{CO}_{2}$. Both cell lines were grown in RPMI-1640 medium supplemented with $10 \%$ fetal bovine serum (FBS) and $1 \%$ penicillin/streptomycin (all from Gibco; Thermo Fisher Scientific, Inc.). EGCG was obtained from Sigma-Aldrich (Merck KGaA). Epidermal growth factor (EGF), basic fibroblast growth factor (bFGF) and insulin were obtained from Peprotech, Inc., and B27 was obtained from Gibco (Thermo Fisher Scientific, Inc.). MTT and dimethyl sulfoxide (DMSO) were obtained from Sigma-Aldrich (Merck KGaA). Purmorphamine was obtained from Selleckchem; it was dissolved in DMSO to make a stock solution at a concentration of $10 \mathrm{mM}$. Antibodies against CD44 (cat. no. 15675), CD133 (cat. no. 18470), Oct4 (cat. no. 60242), ALDH1A1 (cat. no. 15910), Nanog (cat. no. 14295), Bcl2 (cat. no. 12789), Bax (cat. no. 50599), cleaved-caspase-3 (cat. no. 25546), caspase-8 (cat. no. 13423), Cyclin D1 (cat. no. 60186), proliferating cell nuclear antigen (PCNA; cat. no. 24036), Shh (cat. no. 20697), Smo (cat. no. 20787) and GAPDH (cat. no. 10494) were obtained from ProteinTech Group, Inc. Antibodies against cleaved-caspase-9 (cat. no. 9509) were obtained from Cell Signaling Technology, Inc. Antibodies against Gli1 (cat. no. DF7523) and Gli2 (cat. no. DF7541) were obtained from Affinity Biosciences, Inc. The primers of CD44, CD133, Oct4, ALDH1A1, Nanog and GAPDH were acquired from BGI Genomics Co., Ltd. The EJ cell line has been authenticated by short tandem repeat profiling.

Tumorsphere formation assay. The bladder EJ and UM-UC-3 cells were cultured in serum-supplemented medium (SSM), which consisted of RPMI 1640 medium with 10\% FBS and $1 \%$ penicillin/streptomycin. Cells were maintained in the incubator with $5 \% \mathrm{CO}_{2}$ at $37^{\circ} \mathrm{C}$ for $48 \mathrm{~h}$. In order to achieve tumorsphere formation, bladder cancer cells were seeded into 24-well plates at a density of 5,000 cells per well and were cultured in serum-free medium (SFM) consisting of Dulbecco's modified Eagle's medium: Nutrient Mixture F-12 (DMEM/F12; Gibco; Thermo Fisher Scientific, Inc.) with $20 \mathrm{ng} / \mathrm{ml} \mathrm{bFGF,} 20 \mathrm{ng} / \mathrm{ml}$ EGF, $5 \mu \mathrm{g} / \mathrm{ml}$ insulin and $2 \%$ B27 for 3 days, when the tumorspheres began to form. Tumorspheres were maintained in the incubator with $5 \% \mathrm{CO}_{2}$ at $37^{\circ} \mathrm{C}$ for 7 days. Tumorspheres were imaged by an inverted microscope at a magnification of $\times 100$. For investigating the effect of EGCG and purmorphamine on the tumorsphere formation capacity, various concentrations of EGCG $(0,30$, 60 or $90 \mu \mathrm{M})$ or purmorphamine $(1 \mu \mathrm{M})$ were added to each well. After 7 days of treatment in the incubator with $5 \% \mathrm{CO}_{2}$ at $37^{\circ} \mathrm{C}$, the number of EJ and UM-UC-3 tumorspheres $>50 \mu \mathrm{m}$ in diameter that had formed was photographed and counted with the inverted microscope.

Western blot analysis. UM-UC-3 and EJ cells were incubated in SSM, and tumorspheres were incubated in SFM in the incubator with $5 \% \mathrm{CO}_{2}$ at $37^{\circ} \mathrm{C}$. EGCG- and purmorphaminetreated tumorspheres, and cells were washed with PBS, followed by lysing in Radio Immunoprecipitation assay buffer (Beyotime Institute of Biotechnology). Bicinchoninic Acid Protein assay (Pierce; Thermo Fisher Scientific, Inc.) were utilized to detect the concentration of each protein. Proteins (50 $\mu \mathrm{g}$ per lane) were then separated by SDS-PAGE on a $10 \%$ gel and transferred to nitrocellulose membranes (EMD Millipore). After blocking in 5\% non-fat dry milk at room temperature for $1 \mathrm{~h}$, the membranes were incubated with primary antibodies against Cyclin D1, Shh, Nanog (all 1:500 dilution), CD44, CD133, Oct4, ALDH1A1, Bc12, Bax, cleaved-caspase-3, cleaved-caspase-9, caspase-8, PCNA, Smo, Gli1, Gli2 and GAPDH (all 1:1,000 dilution) at $4^{\circ} \mathrm{C}$ overnight. Then they were incubated with horseradish peroxidase-conjugated goat anti-rabbit (cat. no. S0001) or anti-mouse (cat. no. S0002; both 1:10,000 dilution; Affinity Biosciences) immunoglobin $\mathrm{G}$ secondary antibodies for $1 \mathrm{~h}$ at room temperature. GAPDH was used as the loading control. The signals were detected with enhanced chemiluminescence detection system (cat. no. WBKLS0500; EMD Millipore). The target bands were quantified using ImageJ version 1.46 software (National Institutes of Health).

Reverse transcription-quantitative polymerase chain reaction $(R T-q P C R)$. Bladder cancer adherent cells were cultured in SSM, which consisted of RPMI-1640 medium with 10\% FBS and $1 \%$ penicillin/streptomycin, and tumorspheres were cultured in SFM. Bladder cancer adherent cells and tumorspheres were maintained at $37^{\circ} \mathrm{C}$ in an incubator containing $5 \% \mathrm{CO}_{2}$ for 7 days. Total RNA from the cells was isolated with TRIzol reagent (Invitrogen; Thermo Fisher Scientific, Inc.) and transcribed into cDNA using 5X All-In-One RT MasterMix (Applied Biological Materials, Inc.) according to the manufacturers' protocol with $1 \mu \mathrm{g}$ total RNA. The RT-qPCR analysis was performed using the EvaGreen $2 \mathrm{X}$ qPCR MasterMix (Applied Biological Materials, Inc.) and primers of CD44, CD133, Oct4, ALDH1A1, Nanog and GAPDH on the LightCycler ${ }^{\circledR} 96$ real-time PCR detection system (Roche Molecular Systems, Inc.). The mRNA expression for each gene was normalized by GAPDH. The amplification reactions were as follows: An initial hold step $\left(95^{\circ} \mathrm{C}\right.$ for $\left.5 \mathrm{~min}\right)$ and 45 cycles of a two-step PCR $\left(95^{\circ} \mathrm{C}\right.$ for $15 \mathrm{sec}, 54^{\circ} \mathrm{C}$ for $30 \mathrm{sec}$ and $72^{\circ} \mathrm{C}$ for $30 \mathrm{sec}$ ). Fold changes in the expression of each gene were calculated by the $2^{-\triangle \Delta C q}$ method (21). The primer sequences are shown in Table I.

Cell viability analysis. Both bladder cancer cells $\left(1 \times 10^{4} /\right.$ well $)$ were seeded into 96-well plates (Corning Incorporated), which were grown in SSM and incubated with various concentrations of EGCG $(0,30,60,90,120,150$ and $180 \mu \mathrm{M})$ in an incubator with $5 \% \mathrm{CO}_{2}$ at $37^{\circ} \mathrm{C}$ for $48 \mathrm{~h}$. After incubation, $20 \mu \mathrm{l}$ MTT solution $(5 \mathrm{mg} / \mathrm{ml}$ in PBS) was added to each well, and the plates were further incubated for $4 \mathrm{~h}$ at $37^{\circ} \mathrm{C}$. Then, the medium containing MTT was discarded and $150 \mu \mathrm{l}$ DMSO was added 
Table I. Reverse transcription-quantitative polymerase chain reaction sequences.

\begin{tabular}{|c|c|c|}
\hline Gene & Direction & Sequence $\left(5^{\prime}-3^{\prime}\right)$ \\
\hline \multirow[t]{2}{*}{ CD44 } & $\mathrm{F}$ & $\begin{array}{l}\text { GACACATATTGTTTCAATGCTTC } \\
\text { AGC }\end{array}$ \\
\hline & $\mathrm{R}$ & $\begin{array}{l}\text { GATGCCAAGATGATCAGCCATTC } \\
\text { TGGAAT }\end{array}$ \\
\hline \multirow[t]{2}{*}{ CD133 } & $\mathrm{F}$ & TACAACGCCAAACCACGACTGT \\
\hline & $\mathrm{R}$ & $\begin{array}{l}\text { TCTGAACCAATGGAATTCAAGA } \\
\text { CCСTTT }\end{array}$ \\
\hline \multirow[t]{2}{*}{ Oct4 } & $\mathrm{F}$ & TGGGATATACACAGGCCGATG \\
\hline & $\mathrm{R}$ & TCCTCCACCCACTTCTGAG \\
\hline \multirow[t]{2}{*}{ ALDH1A1 } & $\mathrm{F}$ & GCACGCCAGACTTACCTGTC \\
\hline & $\mathrm{R}$ & ССТСCTCAGTTGCAGGATTAAAG \\
\hline \multirow[t]{2}{*}{ Nanog } & $\mathrm{F}$ & TTTGTGGGCCTGAAGAAAACT \\
\hline & $\mathrm{R}$ & AGGGCTGTCCTGAATAAGCAG \\
\hline \multirow[t]{2}{*}{ GAPDH } & $\mathrm{F}$ & CAAGGTCACCATGACAACTTTG \\
\hline & $\mathrm{R}$ & GTCCACCACCCTGTTGCTGTAG \\
\hline
\end{tabular}

$\mathrm{CD}$, cluster of differentiation; ALDH1A1, retinal dehydrogenase 1; $\mathrm{F}$, forward; $\mathrm{R}$, reverse.

to dissolve the formazan crystals. Absorbance was measured at $490 \mathrm{~nm}$ using a microplate reader. All measurements were performed in triplicate.

Cell cycle analysis. Bladder cancer adherent cells, which cultured in SSM, and tumorspheres, which cultured in SFM, were maintained at $37^{\circ} \mathrm{C}$ in an incubator containing $5 \% \mathrm{CO}_{2}$ for 7 days. The cells were collected and then washed twice with ice-cold PBS. Then the cells were fixed in $70 \%$ cold ethanol at $4^{\circ} \mathrm{C}$ overnight. After that, cells were treated with $200 \mu \mathrm{g} / \mathrm{ml}$ PureLinkRNase A, $20 \mu \mathrm{g} / \mathrm{ml}$ propidium iodide (PI) and $0.1 \%$ Triton X-100 (all from Invitrogen; Thermo Fisher Scientific, Inc.) at $37^{\circ} \mathrm{C}$ for $15 \mathrm{~min}$. Next, the cell cycle was analyzed in FACSCalibur $^{\mathrm{TM}}$ (BD Biosciences).

Detection of apoptotic cells by flow cytometry. The apoptosis assay was performed using a fluorescein isothiocyanate (FITC)-Annexin V Apoptosis Detection kit purchased from BD Biosciences. EJ and UM-UC-3 tumorspheres, which cultured in SFM, were seeded into 6-well plates at a density of $1 \times 10^{6} /$ well and treated with various concentrations of EGCG $(0,30,60$ and $90 \mu \mathrm{M})$ for 7 days. Cells were centrifuged at $1,000 \mathrm{x}$ for $5 \mathrm{~min}$ at $4^{\circ} \mathrm{C}$ and washed twice with PBS. Then the cells were resuspended in $100 \mu l$ cold binding buffer, and incubated with $5 \mu \mathrm{l}$ FITC-Annexin-V and $5 \mu \mathrm{l}$ PI. After $1 \mathrm{~min}$ at room temperature in dark, the apoptotic cells were detected by flow cytometry within $1 \mathrm{~h}$. The data were analyzed using FlowJo version 10.0.7 software (FlowJo LLC).

Immunofluorescence staining. EJ and UM-UC-3 tumorspheres, which cultured in SFM, were seeded into 6-well plates at a density of $1 \times 10^{6} /$ well and treated with various concentrations of EGCG $(0,30,60$ and $90 \mu \mathrm{M})$ for 7 days. The bladder tumorspheres were washed in PBS Tween-20 (PBST), fixed with $4 \%$ paraformaldehyde for $15 \mathrm{~min}$ at room temperature, and then were washed three times with PBST. After that, plasma membranes were ruptured with $0.1 \%$ Triton X-100 (Sigma-Aldrich; Merck KGaA) for $30 \mathrm{~min}$. The tumorspheres were then blocked with $5 \%$ bovine serum albumin (Sigma-Aldrich; Merck KGaA) for $1 \mathrm{~h}$ at room temperature and stained with rabbit anti-CD133 antibodies (1:100 dilution) at $4^{\circ} \mathrm{C}$ overnight. They were then stained with FITC-conjugated goat anti-rabbit antibodies (cat. no. S0008; 1:200 dilution; Affinity Biosciences, Inc.) for $2 \mathrm{~h}$ at room temperature. Next, 4',6-diamidino-2-phenylindole (DAPI; Sigma-Aldrich; Merck KGaA) was used to stain the nuclei for $15 \mathrm{~min}$ at room temperature and mounted in aqueous mounting medium (cat. no. ab128982; Abcam). The fluorescent images were imaged using a fluorescence microscope at a magnification of x100.

Cell transfection. EJ and UM-UC-3 cells were seeded into 6-well plates at a density of $2 \times 10^{5}$ cells in RPMI-1640 medium containing 10\% FBS without antibiotics. After $12 \mathrm{~h}$ of incubation at $37^{\circ} \mathrm{C}$, cells were then transiently transfected with Gli1-overexpressing vectors (EX-NEG-M29-Gli1) or control vectors (EX-NEG-M29; both $2 \mu \mathrm{g}$; GeneCopoeia, Inc.) with Lipofectamine Reagent 3000 (Invitrogen; Thermo Fisher Scientific, Inc.) according to the manufacturer's protocols. After $12 \mathrm{~h}$ of transfection, cells were trypsinized and seeded into 24-well plates at a density of 5,000 cells per well containing SFM. Another $12 \mathrm{~h}$ later, cells were treated with or without $60 \mu \mathrm{M}$ EGCG for 4 days. Finally, the western blot analysis was used to detect the protein expression levels.

Statistical analysis. Data are presented as mean \pm standard deviation. Student's t-test was used for comparison between two groups. One-way analysis of variance with Dunnett post hoc test and Tukey test was used for comparison between multiple groups. Statistical tests were performed using Graph-Pad Prism 7.0 software (GraphPad Software, Inc.). $\mathrm{P}<0.05$ indicated that the difference between groups was statistically significant.

\section{Results}

Enrichment of bladder CSCs by SFM culture in vitro. SFM culture is commonly performed to enrich CSCs properties, such as the capability of forming tumorspheres in vitro $(22,23)$. The expression of bladder CSCs markers were examined including CD44, CD133, Oct4, ALDH1A1 and Nanog. As shown in Fig. 1A, bladder adherent cancer cells were grown in SSM and tumorspheres were formed in EJ and UM-UC-3 bladder cancer cells cultured for 7 days in SFM. The protein and mRNA expression levels of bladder CSCs markers were significantly higher in cells grown in SFM compared with those cultured in SSM (Fig. 1B and C). Increasingly, reports have indicated that CSCs were more likely to be quiescent than cancer cells $(24,25)$. Cell cycle analysis showed that the percentage of bladder CSCs in the G1 phase of the cell cycle was greater than that of cells in the $S$ phase (Fig. 1D). It also showed that the percentage of tumorspheres, which were cultured in SFM, in the G1 phase was significantly greater than that of bladder adherent cells, which were cultured in SSM. Compared with 
A
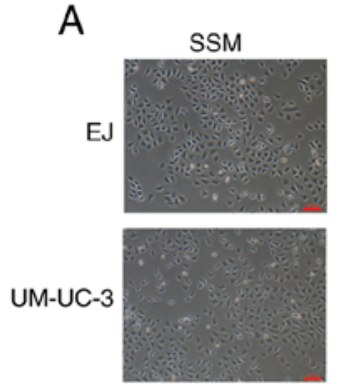

C

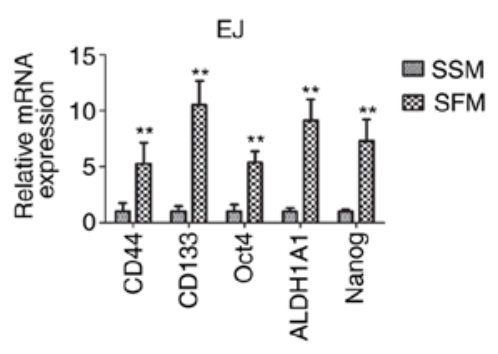

D
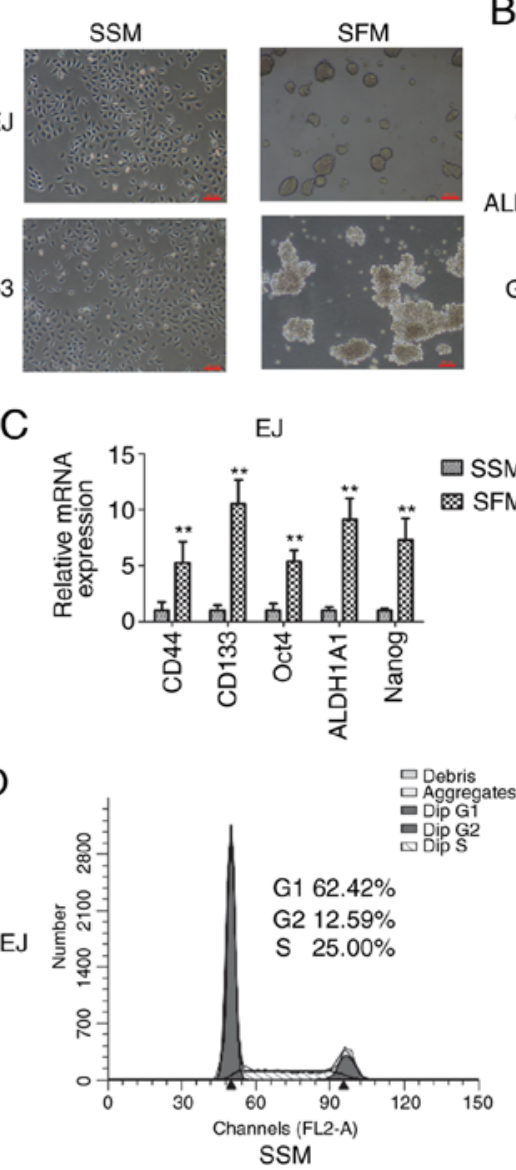

B
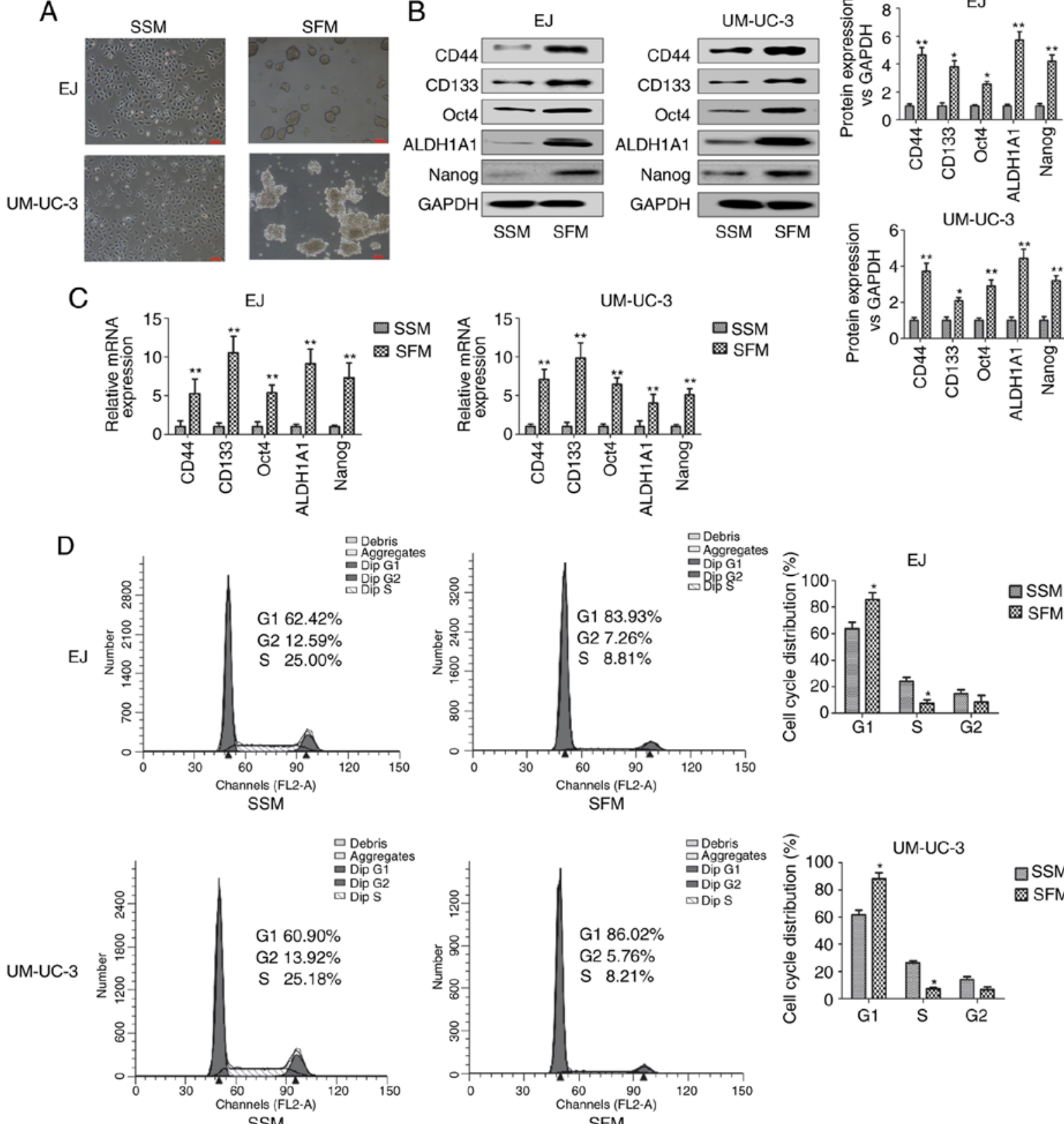

SSM

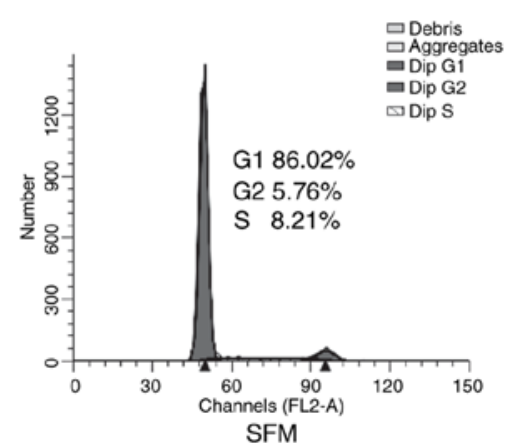

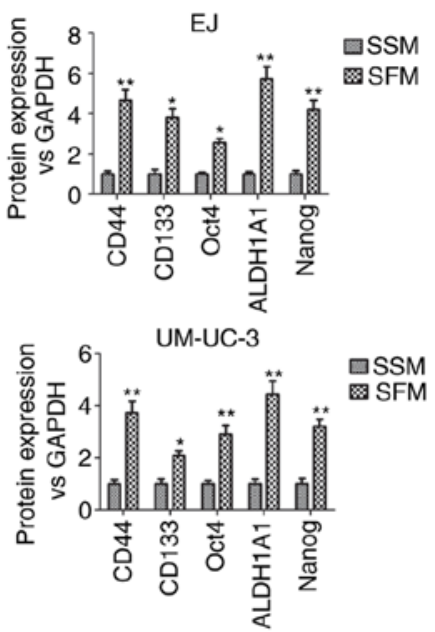

Figure 1. Enrichment of bladder CSCs via culture in SFM. EJ and UM-UC-3 cells were cultured in SSM or SFM for 7 days. (A) Representative images of tumorspheres after culturing. Scale bar, $100 \mu \mathrm{m}$. (B) The protein levels bladder CSCs markers were measured by western blot analysis. (C) The mRNA levels of bladder CSCs markers were examined by reverse transcription-quantitative PCR. (D) Cell cycle was analyzed by flow cytometry. Data are expressed as mean \pm standard deviation. ${ }^{*} \mathrm{P}<0.05,{ }^{* *} \mathrm{P}<0.01$ vs. SSM. SSM, serum-supplied medium; SFM, serum-free medium; CSCs, cancer stem cells.

adherent cells, the percentage of tumorspheres in the G1 phase greater by $\sim 20 \%$, and the percentage of tumorspheres in the $\mathrm{S}$ phase was significantly lower by $17 \%$. This result is consistent with the theory of CSCs. CSCs have been shown to always have a slower growth rate compared with cancer cells as they are resistant to anticancer drugs (26). These results suggested that EJ and UM-UC-3 tumorsphere-forming cells cultured in SFM showed the characteristics of bladder CSCs.

EGCG inhibits bladder CSCs properties. To investigate the effect of EGCG on bladder cancer, cells were treated with EGCG for $48 \mathrm{~h}$, which inhibited cell proliferation in what appeared to be a dose-dependent manner (Fig. 2A). EGCG inhibited the growth of EJ and UM-UC-3 cells with an $\mathrm{IC}_{50}$ of 100.9 and $84.5 \mu \mathrm{M}$ at $48 \mathrm{~h}$, respectively. Treatment of EJ and UM-UC-3 tumorspheres with increasing concentrations of EGCG $(0,30,60$ and $90 \mu \mathrm{M})$ decreased the size and number of bladder tumorspheres in what appeared to be a dose-dependent manner (Fig. 2B and C). The number of tumorspheres in cells treated with 30,60 and $90 \mu \mathrm{M}$ EGCG was significantly lower compared with untreated cells. Western blot analysis showed that the protein expression of bladder CSCs markers was significantly downregulated in the tumorspheres of both cell lines compared with untreated cells (Fig. 2D). In EJ cells, CD44, Oct4 and Nanog were significantly downregulated at 60 and $90 \mu \mathrm{M}$ EGCG, while CD133 and ALDH1A1 were significantly downregulated at 30,60 and $90 \mu \mathrm{M}$ EGCG compared with untreated cells. In UM-UC-3 cells, CD44 and ALDH1A1 were 
A

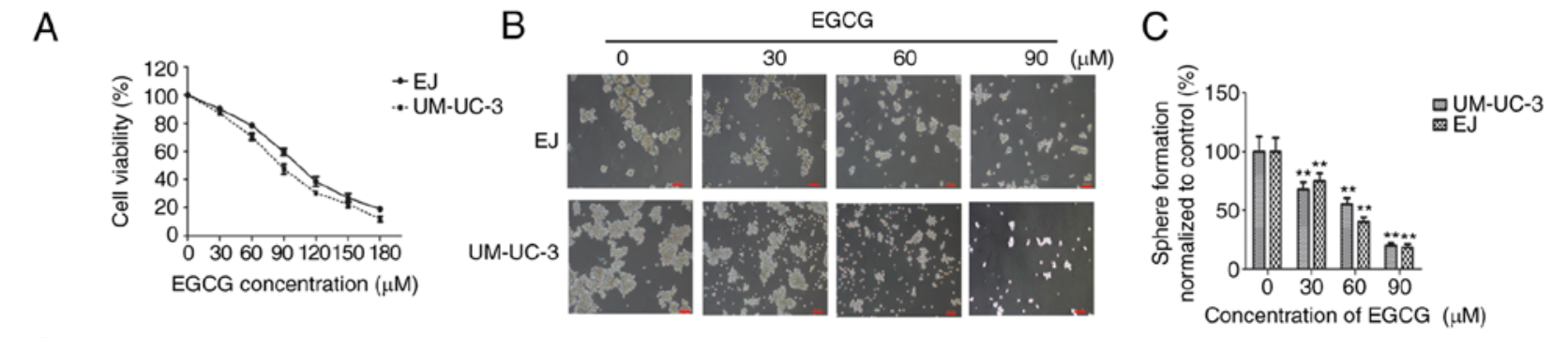

C
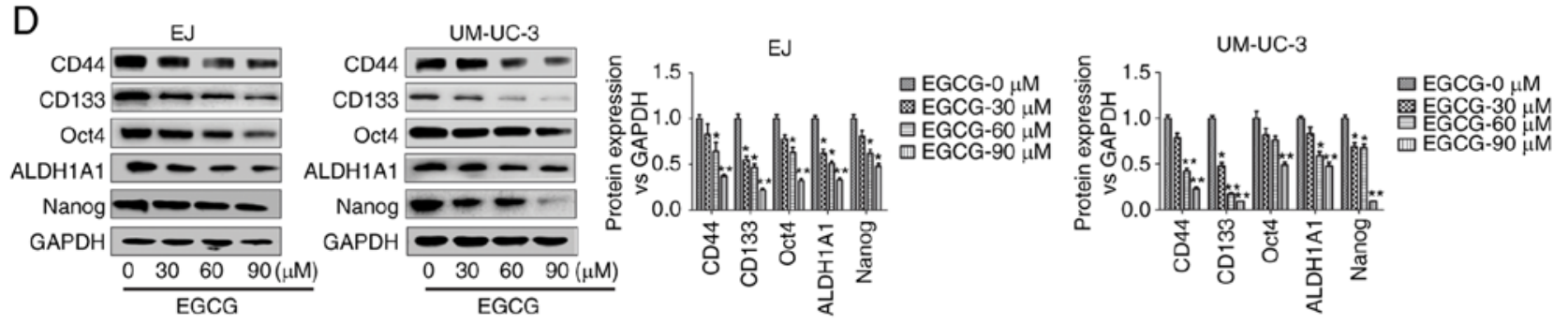

E
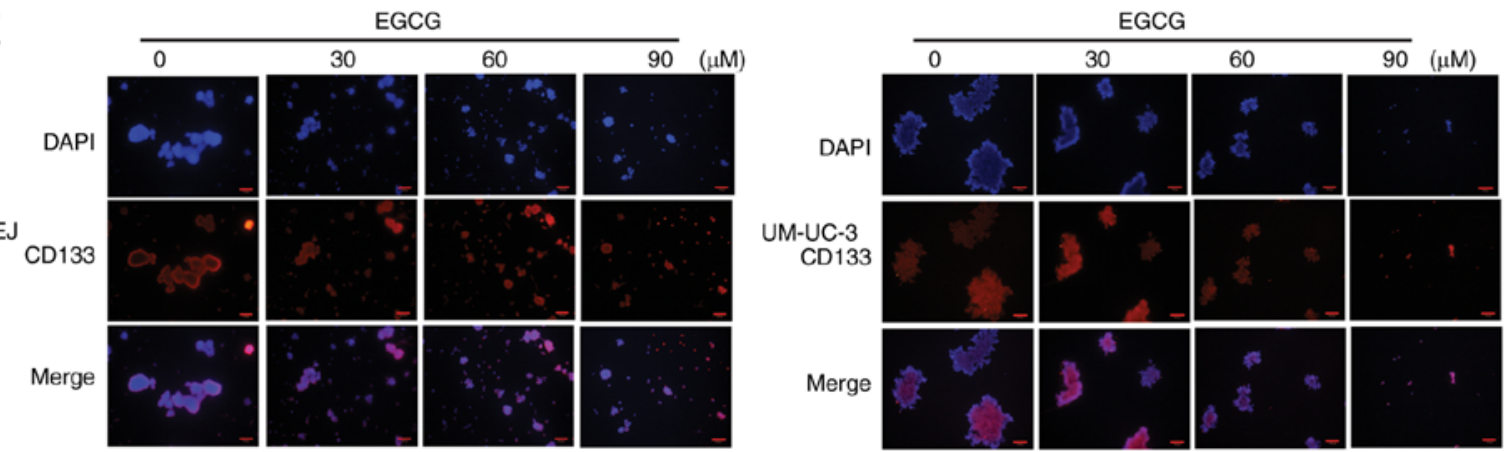

Figure 2. EGCG inhibits bladder CSCs properties. (A) Cytotoxicity of EGCG on EJ and UM-UC-3 bladder cancer cells after a 48-h incubation. Bladder CSCs were treated with different concentrations of EGCG for 7 days. (B) Representative images of tumorspheres after EGCG treatment. Scale bar, $100 \mu$ m. (C) Tumorsphere quantitation (mean \pm standard deviation, $n=3$ ). (D) The protein levels bladder CSCs markers were measured by western blot analysis. (E) Immunofluorescence staining images of tumorspheres were obtained. Scale bar, $100 \mu \mathrm{m}$. Data are expressed as mean \pm standard deviation. ${ }^{*} \mathrm{P}<0.05$, ${ }^{* *} \mathrm{P}<0.01$ vs. the EGCG-0 $\mu \mathrm{m}$ group. EGCG, (-)-epigallocatechin-3-gallate; CSCs, cancer stem cells.

significantly downregulated at 60 and $90 \mu \mathrm{M}$ EGCG, CD133 and Nanog at 30,60 and $90 \mu \mathrm{M}$ EGCG, and Oct4 at $90 \mu \mathrm{M}$ EGCG compared with untreated cells. Immunofluorescent staining showed the seemingly dose-dependent decrease of CD133-positive sphere-forming cells (Fig. 2E). These results indicateed that EGCG inhibited bladder CSCs properties in EJ and UM-UC-3 tumorspheres.

EGCG induces apoptosis and inhibits the expression of proliferation-related proteins in bladder CSCs. Next, the authors examined the effects of EGCG on cell apoptosis and protein expression in bladder CSCs. As shown in Fig. 3A, EGCG treatment significantly downregulated $\mathrm{Bcl}-2$, and significantly upregulated Bax, caspase-8, cleaved caspase-9 and cleaved caspase-3 compared with untreated cells. In EJ cells, Bcl-2 was significantly downregulated at 30,60 and $90 \mu \mathrm{M}$ EGCG. In these cells, Bax and cleaved caspase-3 were significantly upregulated at 30,60 and $90 \mu \mathrm{M}$ EGCG, while caspase- 8 was significantly upregulated at $90 \mu \mathrm{M}$ EGCG and cleaved caspase-9 was significantly upregulated at 60 and $90 \mu \mathrm{M}$ EGCG. In UM-UC-3 cells, Bcl-2 was significantly downregulated at $90 \mu \mathrm{M}$ EGCG, while Bax, caspase-8, cleaved caspase- 9 and cleaved caspase- 3 were significantly upregulated at 30,60 and $90 \mu \mathrm{M}$ EGCG.

EGCG treatment also downregulated the expression of cell proliferation-related proteins PCNA and Cyclin D1 (17)
(Fig. 3B). In UM-UC-3 cells, PCNA was significantly downregulated at $90 \mu \mathrm{M}$ EGCG, while Cyclin D1 was significantly downregulated at 30,60 and $90 \mu \mathrm{M}$ EGCG compared with untreated cells. In EJ cells, PCNA and Cyclin D1 were significantly downregulated at 60 and $90 \mu \mathrm{M}$ EGCG, while only PCNA was significantly downregulated at $30 \mu \mathrm{M}$ EGCG compared with untreated cells. Meanwhile, flow cytometry analysis also showed that EGCG induced apoptosis of sphere-forming cells in both EJ and UM-UC-3 cell lines as the rates of cell apoptosis increased with increasing EGCG doses in what appeared to be a dose-dependent manner (Fig. 3C). These results suggested that EGCG decreased cell proliferation and induced apoptosis in bladder CSCs.

Downregulation of Shh pathway components mediates the inhibitory effect of EGCG on bladder CSCs. To investigate whether EGCG could modulate the sonic hedgehog signaling pathway on bladder CSCs, the expression of Shh-related markers after the treatment of EGCG was analysed. Western blot analysis showed that 30,60 and $90 \mu \mathrm{M}$ EGCG significantly decreased the expression levels of Smo, Shh, Gli1 and Gli2 compared with untreated cells (Fig. 3D). However, no significant differences were observed in Smo expression in EJ cells and Shh expression in UM-UC-3 cells treated with $30 \mu \mathrm{m}$ EGCG. 
A

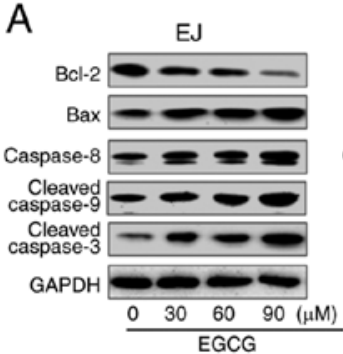

B

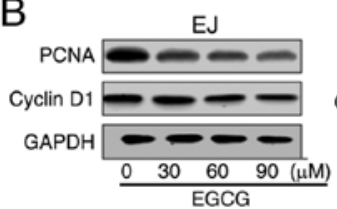

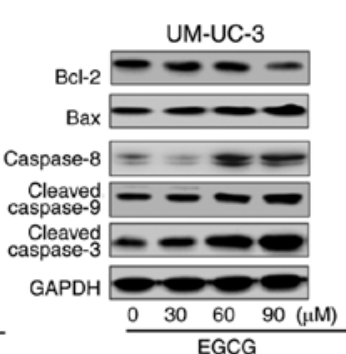

UM-UC-3

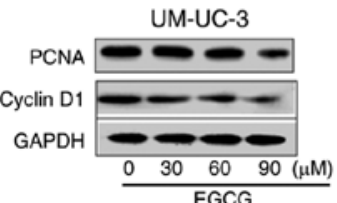

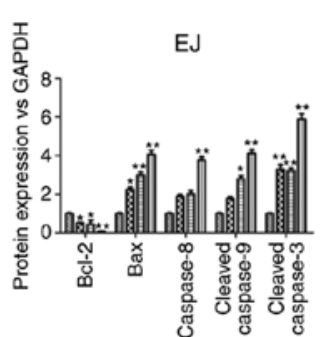

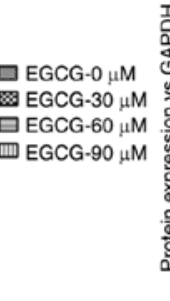

UM-UC-3
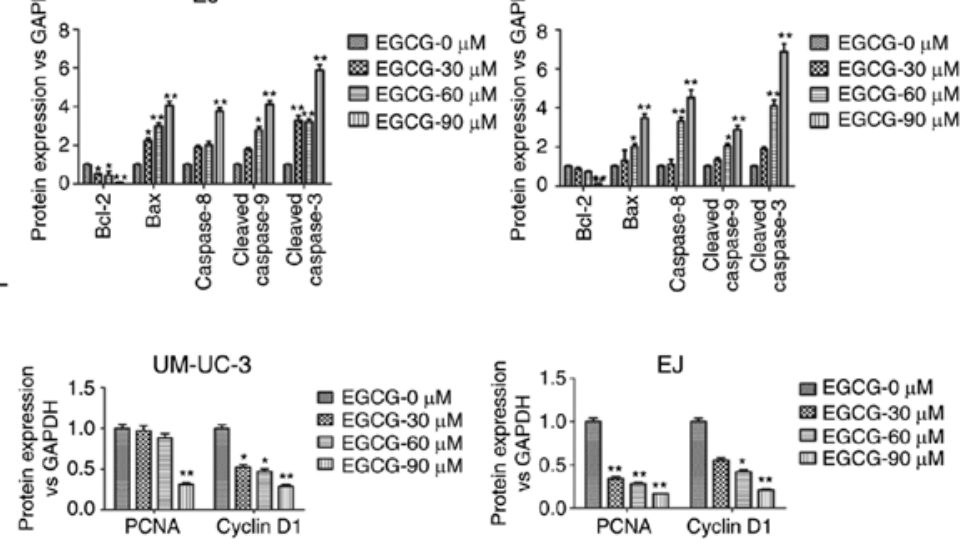

EJ
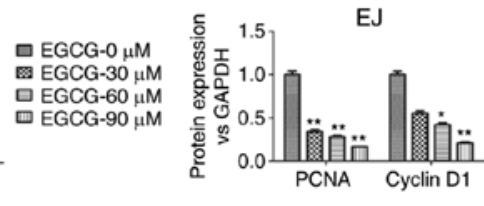

GGCG-0 $\mu \mathrm{M}$ EGCG-30 $\mu \mathrm{M}$ EGCG-60 $\mu \mathrm{M}$
$\square \mathrm{EGCG}-90 \mu \mathrm{M}$

C
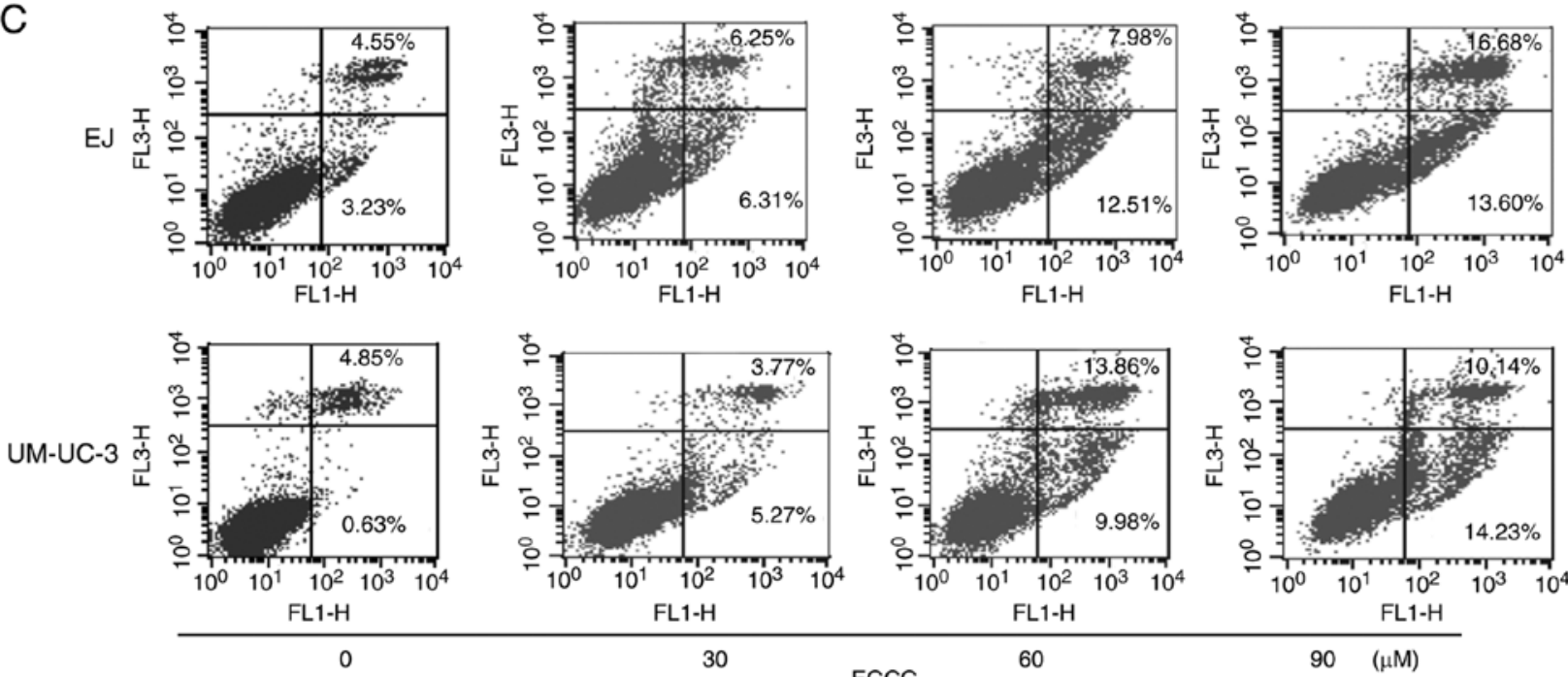

D

EJ

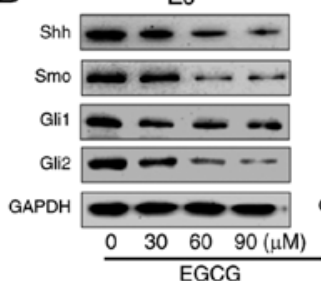

UM-UC-3

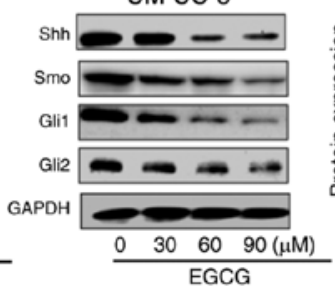

EJ

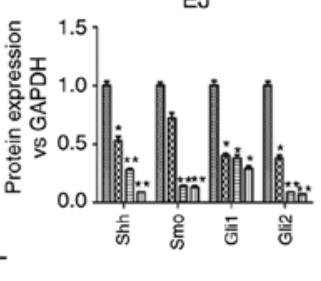

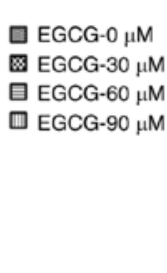

UM-UC-3

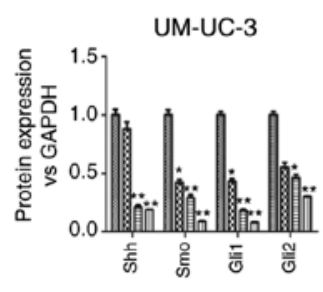

$\square \mathrm{EGCG}-0 \mu \mathrm{M}$ 冈 EGCG-30 $\mu \mathrm{M}$ 目EGCG-60 $\mu \mathrm{M}$ $\square$ EGCG-90 $\mu \mathrm{M}$

Figure 3. EGCG induces apoptosis and reduces the expression of cell proliferation-related proteins on bladder CSCs. Bladder CSCs were treated with different concentrations of EGCG for 7 days. (A) Expression levels of apoptosis-related proteins, including Bcl-2, Bax, caspase-8, cleaved caspase-9 and cleaved caspase-3 were measured by western blot analysis. (B) Expression levels of cell proliferation-related proteins, including PCNA and Cyclin D1 were measured by western blot analysis. (C) Cell apoptosis was analyzed by flow cytometry. (D) The expression levels of Shh signaling pathway-related proteins including Shh, Smo, Gli1 and Gli2 were detected by western blot analysis. Data are expressed as mean \pm standard deviation. ${ }^{*} \mathrm{P}<0.05$, ${ }^{* *} \mathrm{P}<0.01$ vs. the EGCG-0 $\mu \mathrm{m}$ group. EGCG, (-)-epigallocatechin-3-gallate; CSCs, cancer stem cells; PCNA, proliferating cell nuclear antigen; Shh, sonic hedgehog protein; Smo, smoothened homolog; Gli, zinc finger protein GLI.

To further investigate the involvement of the Shh pathway in the effect of EGCG, cells were co-treated with purmorphamine, a specific activator of the Shh pathway (27), and EGCG. As shown in Fig. 4A and 4B, purmorphamine treatment promoted tumorsphere formation and abolished the effect of EGCG on bladder CSCs. EGCG significantly decreased and purmorphamine significantly increased tumorsphere formation compared with untreated cells (Fig. 4B). Tumorsphere formation in EGCG and purmorphamine co-treated cells was similar to untreated cells, and significantly increased when compared with EGCG-treated cells. These results were confirmed by western blot analysis, which showed that the effects of EGCG on the expression of bladder CSCs protein markers (Fig. 4C), cell proliferation-related proteins (Fig. 4D) and apoptosis-related proteins (Fig. 4E) were significantly reversed by purmorphamine-induced Shh signaling pathway activation compared with EGCG-treated cells. In addition, purmorphamine significantly promoted the activation of Shh signaling pathway (Fig. 4F).

To confirm the involvement of the Shh signaling pathway, cells were transfected with Glil-overexpressing plasmids. Overexpression of Gli1 significantly reversed theEGCG-induced 
A

EJ

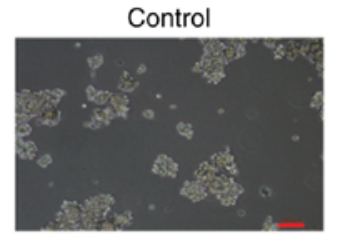

UM-UC-3

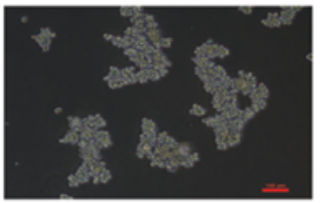

$60 \mu \mathrm{M}$ EGCG
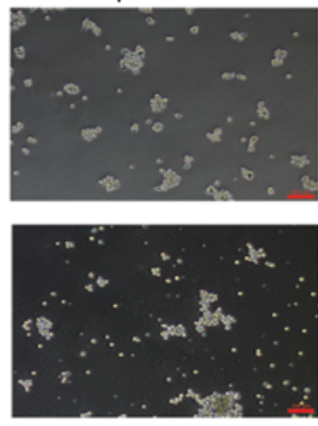

$1 \mu \mathrm{M}$ Purmorphamine
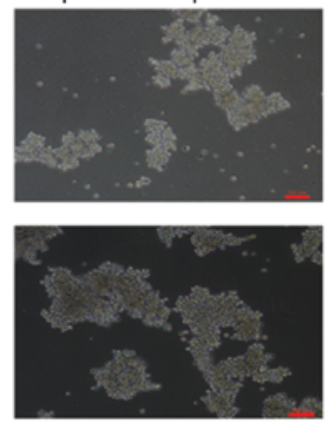

$60 \mu \mathrm{M} \mathrm{EGCG}+1 \mu \mathrm{M}$

Purmorphamine
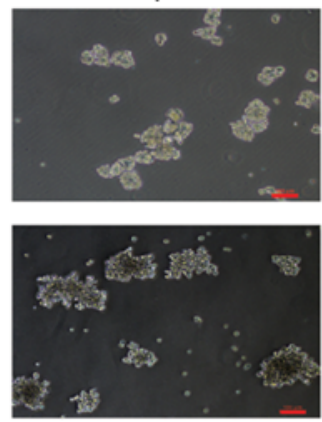

B

\section{B}

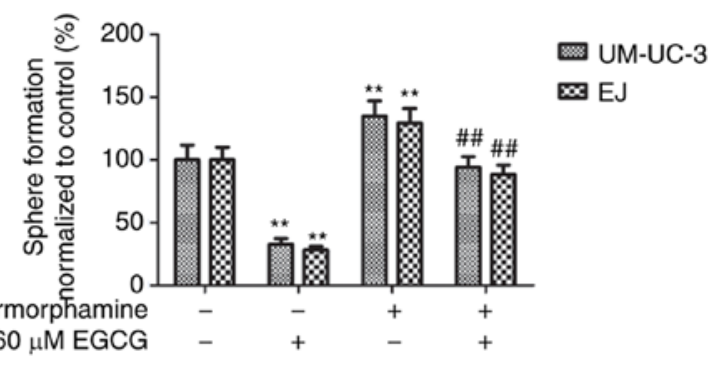

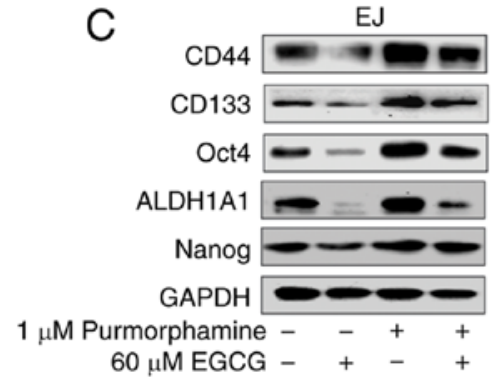

EJ

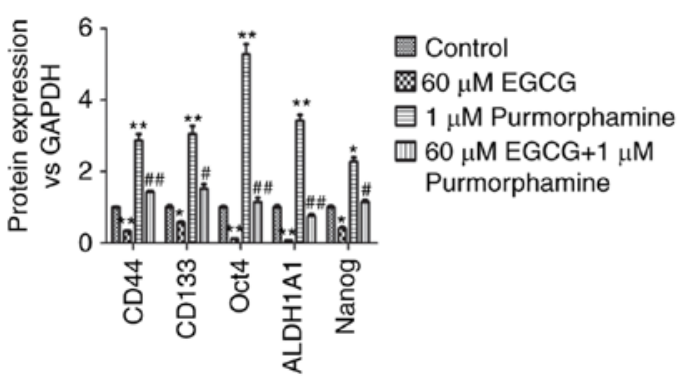

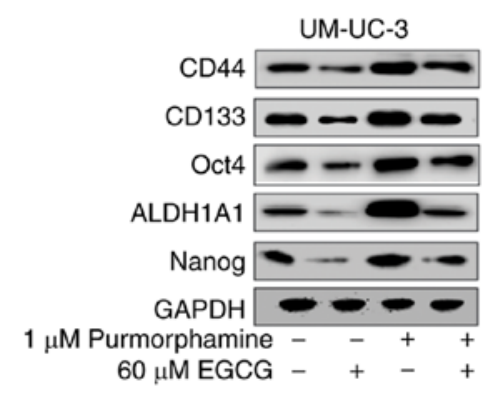

UM-UC-3

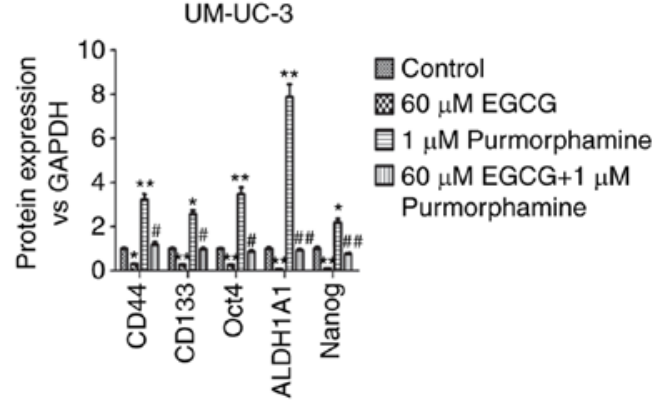

Figure 4. Downregulation of the Shh signaling pathway mediates the inhibitory effects of EGCG on bladder CSCs. Bladder CSCs were treated with EGCG and purmorphamine for 7 days. (A) Representative images of tumorspheres after co-treatment. Scale bar, $100 \mu \mathrm{m}$. (B) Tumorspheres quantitation (mean \pm standard deviation, $\mathrm{n}=3$ ). Western blot analysis was used to measure the protein levels of (C) bladder CSCs markers. Bladder CSCs were transfected with control vector or Glil-overexpressing plasmids, and then treated with $60 \mu \mathrm{M}$ EGCG for 4 days.

downregulation of bladder CSCs markers compared with EGCG-treated cells (Fig. 4G). However, Gli1 expression in EJ cells treated with EGCG and EX-NEG-M29-Gli1 was not significantly different from EJ cells treated with EGCG alone. These results suggested that EGCG inhibited bladder CSCs by suppressing the activity of the Shh signaling pathway.

\section{Discussion}

Previous studies have indicated that the intervention effect of EGCG is common among CSC cell lines (28-30). CSCs play an important role in the recurrence and chemoresistance of bladder cancer; therefore, targeting bladder CSCs is considered to be a critical strategy (9). The Shh signaling pathway plays a significant role in cancer and stem cells, and is involved in maintaining the stemness of CSCs (11). Green tea has been demonstrated to act as cancer preventive for primary cancer prevention and catechins combine with anticancer drugs in tertiary cancer prevention (31). EGCG is the most abundant catechin in green tea and has shown anticancer activity (14). EGCG inhibits breast CSCs by decreasing the expression levels of the proliferation markers Cyclin D1 (32). EGCG also upregulates Bax, caspase-8, and cleaved caspases- 3 and -9 in lung CSCs (17). 

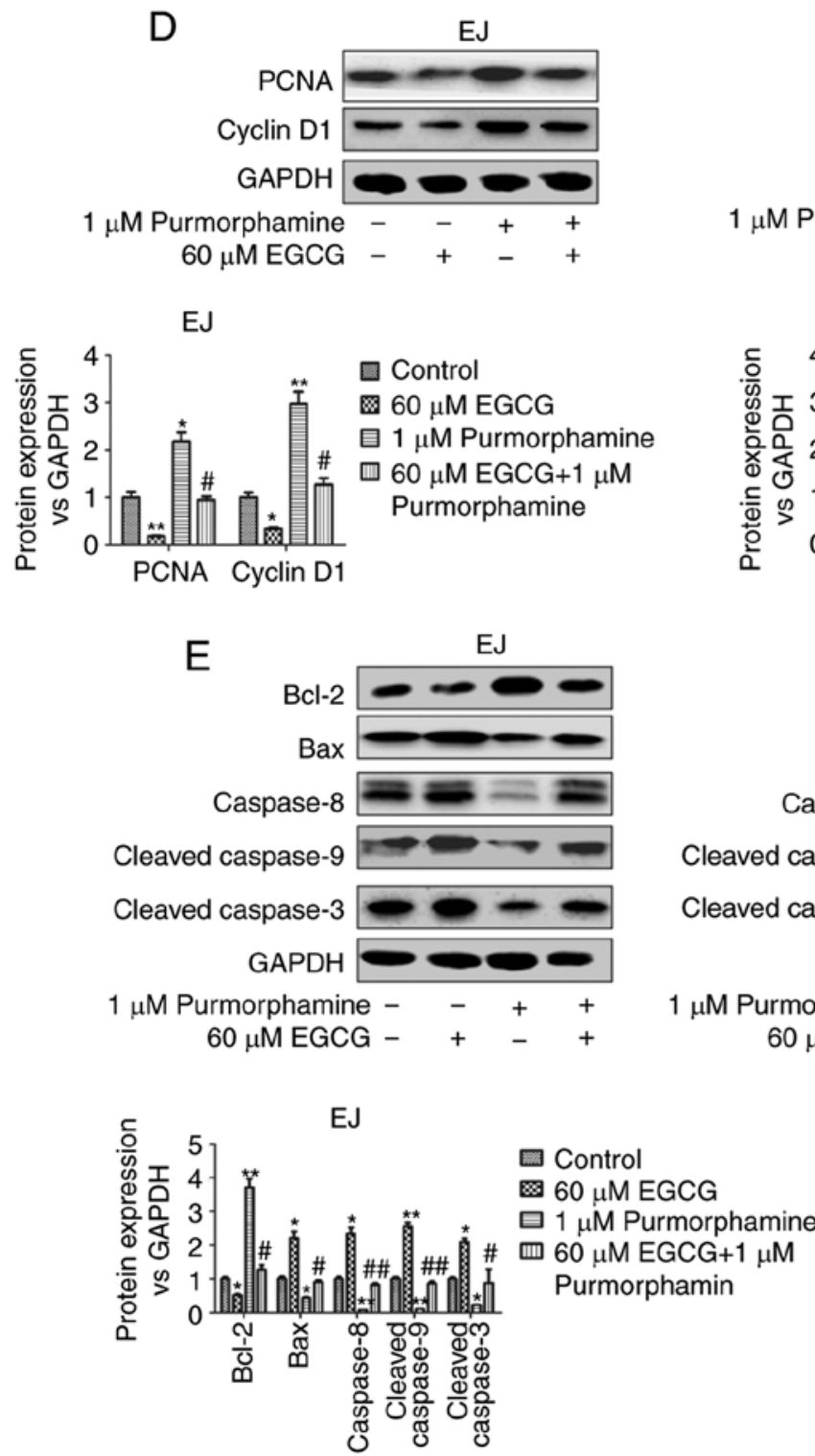

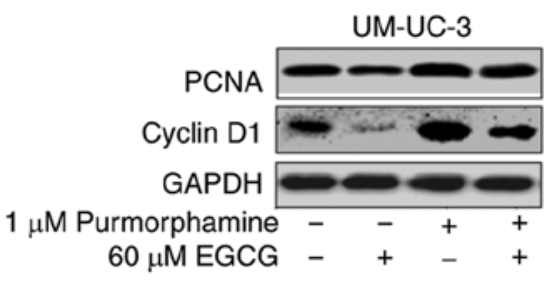

UM-UC-3
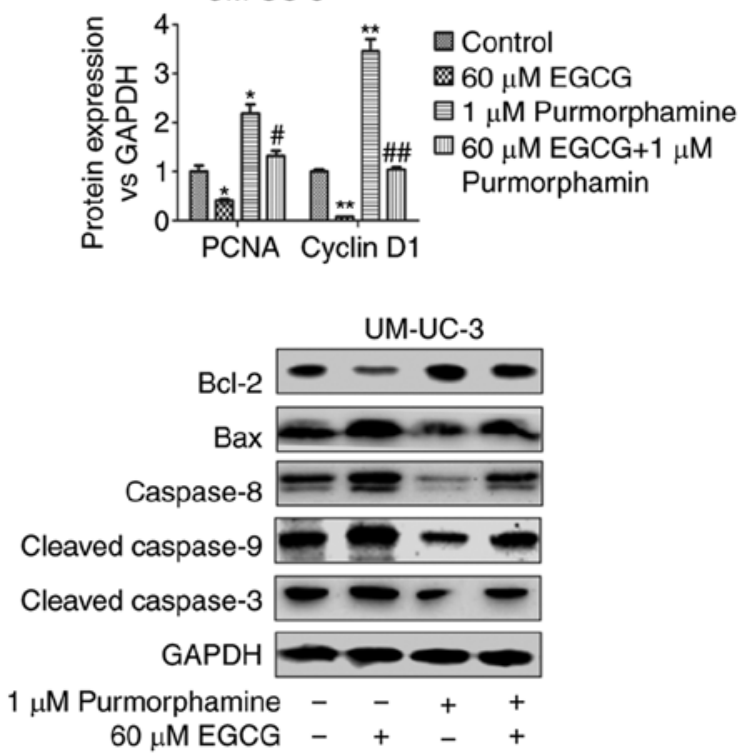

Figure 4. Continued. Western blot analysis was used to measure the protein levels of (D) cell proliferation-related proteins and (E) cell apoptosis-related proteins. Bladder CSCs were transfected with control vector or Gli1-overexpressing plasmids, and then treated with $60 \mu \mathrm{M}$ EGCG for 4 days.

Here, the authors of the present study demonstrated that EGCG inhibited bladder CSCs by targeting the Shh signaling pathway. In the present study, bladder CSCs were isolated from adherent bladder cancer EJ and UM-UC-3 cells using the SFM culture system. SFM is a commonly used method for the enrichment of CSCs according to the characteristics of stem cells (33). In in vitro experiments, cells cultured in SFM formed three-dimensional tumorspheres, and the expression of bladder CSCs markers (CD44, CD133, Oct4, ALDH1A and, Nanog) was upregulated. Evidence showed that $\mathrm{CD} 133^{+}$bladder cancer cells exhibited higher tumorigenic potential and chemoresistance than CD133- cells (34). CD44+ bladder cancer was first isolated from tumor specimens and associated with poor clinical outcomes in bladder cancer (10). ALDH1A1 has been associated with poor prognosis in urothelial carcinoma (35). Nanog and Oct4 have been shown to be expressed at high levels in bladder cancer, and play a significant role in tumor carcinogenesis $(36,37)$. A cell cycle analysis detected a greater percentage of EJ and UM-UC-3 tumorspheres contained cells

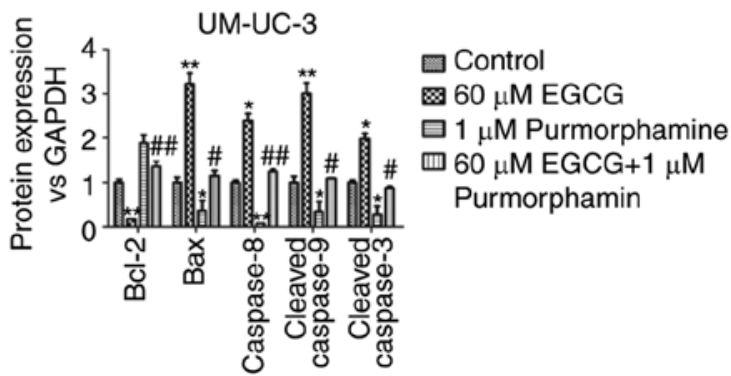

in the G1 phase than cells in the S phase (38). These results were consistent with the theory of stem cells, as CSCs are mostly quiescent cells; they may survive treatment, rebuild tumors and subsequently become the cause of resistance to cancer treatment (39). The present data suggest that cells acquired stem cells characteristics when cultured in SFM in vitro.

Increasing evidence supports the role of natural products in inhibiting tumor cells, including CSCs. The effect of common natural products, such as curcumin, sulforaphane and diallyl trisulfide, on inhibiting CSCs has been shown, and studies have indicated that they contribute to the chemotherapy for cancers (40-42). Tessmann et al (43) found that 1-thiocarbamoyl-3,5-diaryl-4,5-dihydro-1H-pyrazole, as one of the derivatives of pyrazoline, has an antitumor potential towards bladder cancer. Liu et al (44) showed that metformin repressed bladder CSCs through the prostaglandin G/H synthase 2/prostaglandin E2/STAT3 signaling pathway. Natural products have shown potential in the prevention and treatment of different tumors (45). EGCG is an important polyphenol antioxidant 
$\mathrm{F}$
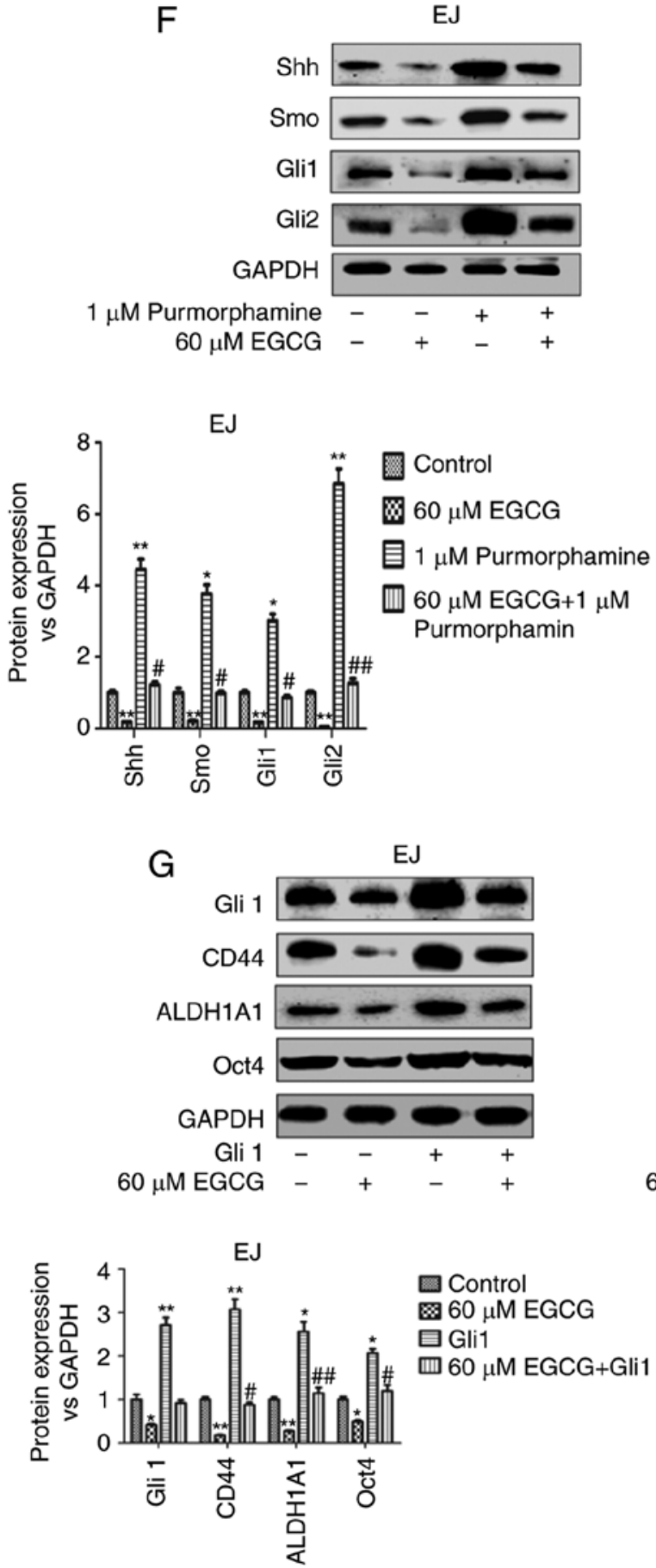
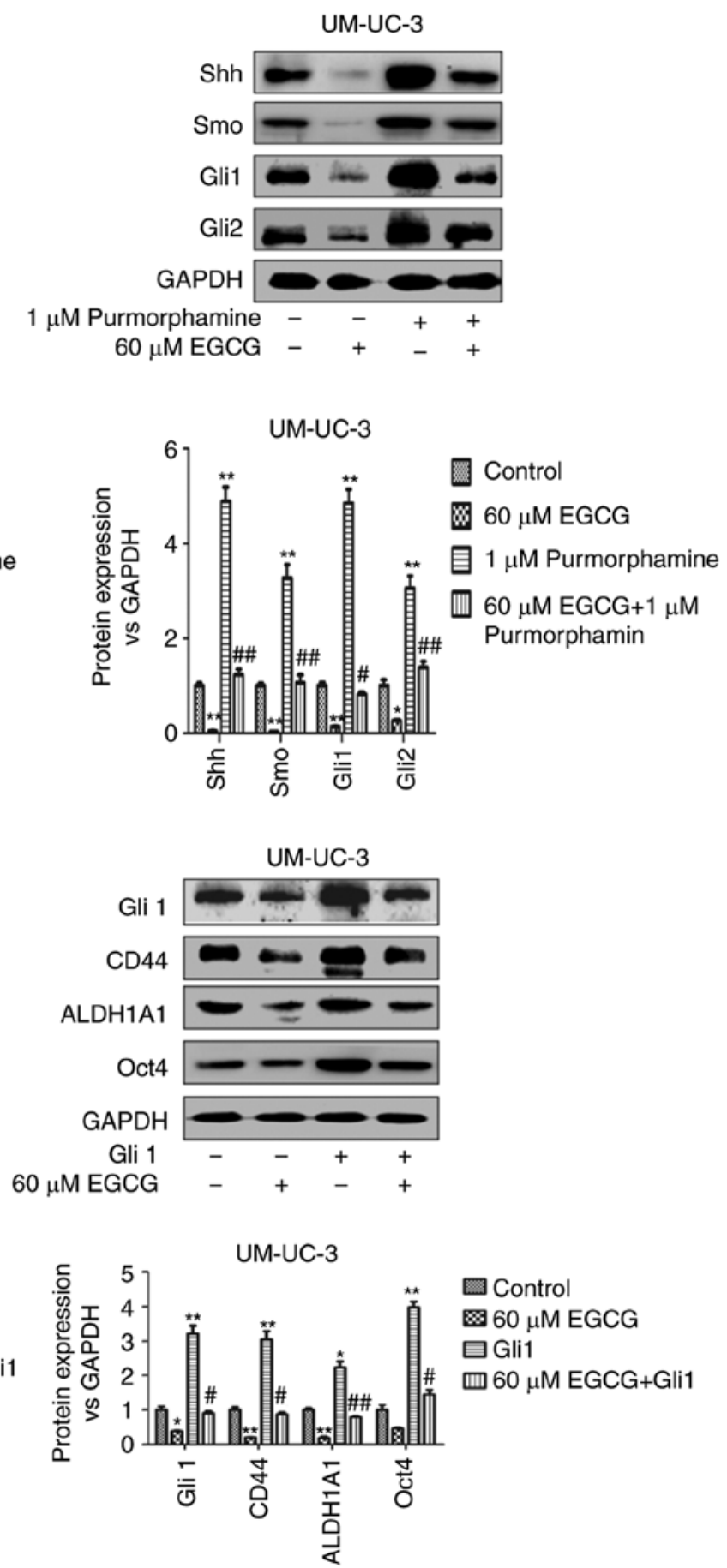

Figure 4. Continued. Western blot analysis was used to measure the protein levels of (F) Shh signaling pathway-related proteins. Bladder CSCs were transfected with control vector or Gli1-overexpressing plasmids, and then treated with $60 \mu \mathrm{M}$ EGCG for 4 days. (G) Western blot analysis was used to measure the protein levels of bladder CSCs markers. Data are expressed as mean \pm standard deviation. ${ }^{*} \mathrm{P}<0.05,{ }^{* *} \mathrm{P}<0.01$ vs. the control group. ${ }^{\#} \mathrm{P}<0.05$, ${ }^{\# \#} \mathrm{P}<0.01$ vs. the $60 \mu \mathrm{M}$ EGCG group. EGCG, (-)-epigallocatechin-3-gallate; CSCs, cancer stem cells; Shh, sonic hedgehog protein; Smo, smoothened homolog; Gli, zinc finger protein GLI; CD, cluster of differentiation; ALDH1A1, retinal dehydrogenase 1; PCNA, proliferating cell nuclear antigen.

from green tea, and its antitumor effect on bladder tumors involves different pathways (31). In the present study, the authors showed that EGCG suppressed the bladder CSCs properties by decreasing tumorsphere formation activity and reducing the expression of bladder CSCs markers. Moreover, EGCG inhibited the expression of cell proliferation-related proteins and stimulated the apoptosis of bladder CSCs. These data indicated that EGCG exhibits a suppressive effect on bladder CSCs.
Increasingly, studies are demonstrating the role of the Shh signaling pathway in the maintenance of CSCs $(11,33)$. During early development, Shh is expressed in the notochord and promotes the development of the bladder (46). The secreted Shh molecule represses Ptch1, thereby activating the Gli transcription factor in target cells during urothelial mesenchymal differentiation (47). In bladder cancer, Shh signaling pathway activation is related to tumor development and metastasis (13). Additionally, Gli1 and Gli2 overexpression 
promotes mammosphere formation and increases mammosphere size (48). However, the involvement of the Shh signaling pathway in the effect of EGCG on bladder CSCs remains poorly understood. Therefore, the authors of the current study aimed to determine whether the Shh signaling pathway mediates the effect of EGCG on bladder CSCs.

In the present study, it was showed that the Shh signaling pathway was significantly downregulated after EGCG treatment of bladder CSCs, as evidenced by the decreased expression of Smo, Shh, Gli1 and Gli2. Purmorphamine is a Shh signaling pathway agonist that targets the Smo transmembrane protein $(39,49,50)$. Wu et al (49) showed that purmorphamine treatment upregulated the expression of Gli1 and Gli2. The current study showed that activation of the Shh signaling pathway by purmorphamine abolished the effects of EGCG on tumorsphere formation activity, the expression of stem cell markers and cell proliferation-related proteins, and apoptosis in bladder CSCs. Overexpression of Glil has been previously shown to upregulate CD44, ALDH1A1 and Oct4 (51-53).

Taken together, these results indicated that the suppressive effect of EGCG on bladder CSCs is mediated by Shh signaling pathway inhibition. However, the current study is based on in vitro findings involving a SFM culture system. Additional in vivo studies are warranted to validate the findings of the current study and other CSCs model in bladder cancer, such as side population and cell isolation using specific markers.

In conclusion, the present demonstrated that EGCG suppressed bladder CSCs by inhibiting the Shh signaling pathway. These findings provide new insight into the potential mechanism underlying the effect of EGCG on bladder cancer.

\section{Acknowledgements}

Not applicable.

\section{Funding}

This work was supported by grants from the National Natural Science Foundation of China (grant no. 81373005), Anhui Medical University scientific research funds (Hefei, China; grant no. H0514) and the Natural Science Foundation of Anhui Province (grant no. 1608085QH173).

\section{Availability of data and materials}

The analyzed data sets generated during the study are available from the corresponding author on reasonable request.

\section{Authors' contributions}

DY and CZ designed the experiment. XS, JS, EL, HG and YL performed the experiment. XS analyzed the data and wrote the manuscript. All authors read and approved the final manuscript.

\section{Ethics approval and consent to participate}

Not applicable.

\section{Patient consent for publication}

Not applicable.

\section{Competing interest}

The authors declare that they have no conflict of interest.

\section{References}

1. Witjes JA, Compérat E, Cowan NC, De Santis M, Gakis G, Lebret T, Ribal MJ, Van der Heijden AG and Sherif A; European Association of Urology: EAU guidelines on muscle-invasive and metastatic bladder cancer: Summary of the 2013 guidelines. Eur Urol 65: 778-792, 2014

2. DeGeorge KC, Holt HR and Hodges SC: Bladder cancer: Diagnosis and treatment. Am Fam Physician 96: 507-514, 2017.

3. Siegel RL, Miller KD and Jemal A: Cancer Statistics, 2018. CA Cancer J Clin 68: 7-30, 2018.

4. Dinney CP,McConkey DJ,Millikan RE, Wu X,Bar-Eli M,Adam L, Kamat AM, Siefker-Radtke AO, Tuziak T, Sabichi AL, et al: Focus on bladder cancer. Cancer Cell 6: 111-116, 2004.

5. Zhang Y, Wang Z, Yu J, Shi JZ, Wang C, Fu WH, Chen ZW and Yang J: Cancer stem-like cells contribute to cisplatin resistance and progression in bladder cancer. Cancer Lett 322: 70-77, 2012.

6. Li Y, Lin K, Yang Z, Han N, Quan X, Guo X, Li C: Bladder cancer stem cells: Clonal origin and therapeutic perspectives. Oncotarget 8: 66668-66679, 2017.

7. Shiozawa Y, Nie B, Pienta KJ, Morgan TM and Taichman RS: Cancer stem cells and their role in metastasis. Pharmacol Ther 138: 285-293, 2013.

8. Shervington A and $\mathrm{Lu} \mathrm{C}$ : Expression of multidrug resistance genes in normal and cancer stem cells. Cancer Invest 26: 535-542, 2008.

9. Hatina J, Parmar HS, Kripnerova M, Hepburn A and Heer R: Urothelial carcinoma stem cells: Current concepts, controversies, and methods. Methods Mol Biol 1655: 121-136, 2018.

10. Chan KS, Espinosa I, Chao M, Wong D, Ailles L, Diehn M, Gill H, Presti J Jr, Chang HY, van de Rijn M, et al: Identification, molecular characterization, clinical prognosis, and therapeutic targeting of human bladder tumor-initiating cells. Proc Natl Acad Sci USA 106: 14016-14021, 2009.

11. Syed IS, Pedram A and Farhat WA: Role of sonic hedgehog (Shh) signaling in bladder cancer stemness and tumorigenesis. Curr Urol Rep 17: 11, 2016.

12. Qian W, Kong X, Zhang T, Wang D, Song J, Li Y, Li X, Geng H, Min J, Kong Q, et al: Cigarette smoke stimulates the stemness of renal cancer stem cells via sonic hedgehog pathway. Oncogenesis 7: 24, 2018.

13. Islam SS, Mokhtari RB, Noman AS, Uddin M, Rahman MZ, Azadi MA, Zlotta A, van der Kwast T, Yeger H and Farhat WA: Sonic hedgehog (Shh) signaling promotes tumorigenicity and stemness via activation of epithelial-to-mesenchymal transition (EMT) in bladder cancer. Mol Carcinog 55: 537-551, 2016.

14. Fujiki H, Watanabe T, Sueoka E, Rawangkan A and Suganuma M: Cancer prevention with green tea and its principal constituent, EGCG: From early investigations to current focus on human cancer stem cells. Mol Cells 41: 73-82, 2018.

15. Luo KW, Chen W, Lung WY, Wei XY, Cheng BH, Cai ZM and Huang WR: EGCG inhibited bladder cancer SW780 cell proliferation and migration both in vitro and in vivo via downregulation of NF- $\kappa B$ and MMP-9. J Nutr Biochem 41: 56-64, 2017.

16. Luo KW, Lung WY, Chun-Xie, Luo XL and Huang WR: EGCG inhibited bladder cancer $\mathrm{T} 24$ and 5637 cell proliferation and migration via PI3K/AKT pathway. Oncotarget 9: 12261-12272, 2018.

17. Zhu J, Jiang Y, Yang X, Wang S, Xie C, Li X, Li Y, Chen Y, Wang $\mathrm{X}$, Meng Y, et al: Wnt/ $\beta$-catenin pathway mediates (-)-Epigallocatechin-3-gallate (EGCG) inhibition of lung cancer stem cells. Biochem Biophys Res Commun 482: 15-21, 2017.

18. Chen Y, Wang XQ, Zhang Q, Zhu JY, Li Y, Xie CF, Li XT, Wu JS, Geng SS, Zhong CY and Han HY: (-)-Epigallocatechin-3-Gallate inhibits colorectal cancer stem cells by suppressing Wnt/ $\beta$-catenin pathway. Nutrients 9: E572, 2017.

19. Lin $\mathrm{CH}$, Chao LK, Hung PH and Chen YJ: EGCG inhibits the growth and tumorigenicity of nasopharyngeal tumor-initiating cells through attenuation of STAT3 activation. Int J Clin Exp Pathol 7: 2372-2381, 2014. 
20. Fujiki H, Sueoka E, Watanabe T and Suganuma M: Synergistic enhancement of anticancer effects on numerous human cancer cell lines treated with the combination of EGCG, other green tea catechins, and anticancer compounds. J Cancer Res Clin Oncol 141: 1511-1522, 2015.

21. Livak KJ and Schmittgen TD: Analysis of relative gene expression data using real-time quantitative PCR and the 2(-Delta Delta C(T)) method. Methods 25: 402-408, 2001.

22. Sun FF, Hu YH, Xiong LP, Tu XY, Zhao JH, Chen SS, Song J and Ye XQ: Enhanced expression of stem cell markers and drug resistance in sphere-forming non-small cell lung cancer cells. Int J Clin Exp Pathol 8: 6287-6300, 2015.

23. Pozzi V,Sartini D, Rocchetti R, Santarelli A,Rubini C,Morganti S, Giuliante R, Calabrese S, Di Ruscio G, Orlando F, et al: Identification and characterization of cancer stem cells from head and neck squamous cell carcinoma cell lines. Cell Physiol Biochem 36: 784-798, 2015.

24. Clarke MF, Dick JE, Dirks PB, Eaves CJ, Jamieson CH, Jones DL, Visvader J, Weissman IL and Wahl GM: Cancer stem cells-perspectives on current status and future directions: AACR Workshop on cancer stem cells. Cancer Res 66: 9339-9344, 2006.

25. Williams SA, Anderson WC, Santaguida MT and Dylla SJ Patient-derived xenografts, the cancer stem cell paradigm, and cancer pathobiology in the 21st century. Lab Invest 93: 970-982, 2013.

26. Ohishi T, Koga F and Migita T: Bladder cancer stem-like cells: Their origin and therapeutic perspectives. Int J Mol Sci 17: E43, 2015.

27. Sinha S and Chen JK: Purmorphamine activates the hedgehog pathway by targeting Smoothened. Nat Chem Biol 2: 29-30, 2006.

28. Wubetu GY, Shimada M, Morine Y, Ikemoto T, Ishikawa D, Iwahashi S, Yamada S, Saito Y, Arakawa Y and Imura S: Epigallocatechin gallate hinders human hepatoma and colon cancer sphere formation. J Gastroenterol Hepatol 31: 256-264, 2016.

29. Jiang P, Xu C, Chen L, Chen A, Wu X, Zhou M, Haq IU, MariyamZ and Feng Q: Epigallocatechin-3-gallate inhibited cancer stem cell-like properties by targeting hsa-mir-485-5p/RXR $\alpha$ in lung cancer. J Cell Biochem 119: 8623-8635, 2018

30. Toden S, Tran HM, Tovar-Camargo OA, Okugawa Y and Goel A Epigallocatechin-3-gallate targets cancer stem-like cells and enhances 5-fluorouracil chemosensitivity in colorectal cancer. Oncotarget 7: 16158-16171, 2016.

31. Fujiki H, Sueoka E, Rawangkan A and Suganuma M: Human cancer stem cells are a target for cancer prevention using (-)-epigallocatechin gallate. J Cancer Res Clin Oncol 143: 2401-2412, 2017

32. Mineva ND, Paulson KE, Naber SP, Yee AS and Sonenshein GE: Epigallocatechin-3-gallate inhibits stem-like inflammatory breast cancer cells. PLoS One 8: e73464, 2013.

33. Wang D, Kong X, Li Y, Qian W, Ma J, Wang D, Yu D and Zhong C: Curcumin inhibits bladder cancer stem cells by suppressing sonic hedgehog pathway. Biochem Biophys Res Commun 493: 521-527, 2017.

34. Huang $P$, Watanabe $M$, Kaku H, Ueki H, Noguchi $H$ Sugimoto M, Hirata T, Yamada H, Takei K, Zheng S, et al: Cancer stem cell-like characteristics of a CD133+ subpopulation in the J82 human bladder cancer cell line. Mol Clin Oncol 1: 180-184, 2013.

35. Keymoosi H, Gheytanchi E, Asgari M, Shariftabrizi A and Madjd Z: ALDH1 in combination with CD44 as putative cancer stem cell markers are correlated with poor prognosis in urothelial carcinoma of the urinary bladder. Asian Pac J Cancer Prev 15: 2013-2020, 2014

36. Sedaghat S, Gheytanchi E, Asgari M, Roudi R, Keymoosi H and Madjd Z: Expression of cancer stem cell markers OCT4 and CD133 in transitional cell carcinomas. Appl Immunohistochem Mol Morphol 25: 196-202, 2017.
37. Amini S, Fathi F, Mobalegi J, Sofimajidpour H and Ghadimi T: The expressions of stem cell markers: Oct4, Nanog, Sox2, nucleostemin, Bmi, Zfx, Tcl1, Tbx3, Dppa4, and Esrrb in bladder, colon, and prostate cancer, and certain cancer cell lines. Anat Cell Biol 47: 1-11, 2014.

38. Morata-Tarifa C, Jiménez G, García MA, Entrena JM, Griñán-Lisón C, Aguilera M,Picon-Ruiz M and Marchal JA: Low adherent cancer cell subpopulations are enriched in tumorigenic and metastatic epithelial-to-mesenchymal transition-induced cancer stem-like cells. Sci Rep 6: 18772, 2016.

39. Zhu J, Yang X, Chen Y, Jiang Y, Wang SJ, Li Y, Wang XQ, Meng Y,Zhu MM, Ma X, et al: Curcumin suppresses lung cancer stem cells via inhibiting Wnt/ $\beta$-catenin and sonic hedgehog pathways. Phytother Res 31: 680-688, 2017.

40. Li X, Meng Y, Xie C, Zhu J, Wang X, Li Y, Geng S, Wu J, Zhong C and Li M: Diallyl Trisulfide inhibits breast cancer stem cells via suppression of Wnt/ $\beta$-catenin pathway. J Cell Biochem 119: 4134-4141, 2018

41. Wang F, Wang W, Li J, Zhang J, Wang $X$ and Wang $M$ : Sulforaphane reverses gefitinib tolerance in human lung cancer cells via modulation of sonic hedgehog signaling. Oncol Lett 15: 109-114, 2018.

42. Li X, Wang X, Xie C, Zhu J, Meng Y, Chen Y, Li Y, Jiang Y, Yang $\mathrm{X}$, Wang S, et al: Sonic hedgehog and Wnt/ $\beta$-catenin pathways mediate curcumin inhibition of breast cancer stem cells Anticancer Drugs 29: 208-215, 2018.

43. Tessmann JW, Buss J, Begnini KR, Berneira LM, Paula FR, de Pereira CM, Collares T and Seixas FK: Antitumor potential of 1-thiocarbamoyl-3,5-diaryl-4,5-dihydro-1H-pyrazoles in human bladder cancer cells. Biomed Pharmacother 94: 37-46, 2017.

44. Liu Q, Yuan W, Tong D, Liu G, Lan W, Zhang D, Xiao H, Zhang Y, Huang Z, Yang J, et al: Metformin represses bladder cancer progression by inhibiting stem cell repopulation via COX2/PGE2/STAT3 axis. Oncotarget 7: 28235-28246, 2016.

45. Dutta S, Mahalanobish S, Saha S, Ghosh S and Sil PC: Natural products: An upcoming therapeutic approach to cancer. Food Chem Toxicol 128: 240-255, 2019.

46. Villavicencio EH, Walterhouse DO and Iannaccone PM: The sonic hedgehog-patched-gli pathway in human development and disease. Am J Hum Genet 67: 1047-1054, 2000.

47. DeSouza KR, Saha M, Carpenter AR, Scott M and McHugh KM: Analysis of the sonic hedgehog signaling pathway in normal and abnormal bladder development. PLoS One 8: e53675, 2013.

48. Liu S, Dontu G, Mantle ID, Patel S, Ahn NS, Jackson KW, Suri $\mathrm{P}$ and Wicha MS: Hedgehog signaling and Bmi-1 regulate self-renewal of normal and malignant human mammary stem cells. Cancer Res 66: 6063-6071, 2006.

49. Wu X, Walker J, Zhang J, Ding S and Schultz PG: Purmorphamine induces osteogenesis by activation of the hedgehog signaling pathway. Chem Biol 11: 1229-1238, 2004.

50. Oliveira FS, Bellesini LS, Defino HL, da Silva Herrero CF, Beloti MM and Rosa AL: Hedgehog signaling and osteoblast gene expression are regulated by purmorphamine in human mesenchymal stem cells. J Cell Biochem 113: 204-208, 2012.

51. Xu M, Gong A, Yang H, George SK, Jiao Z, Huang H, Jiang X and Zhang Y: Sonic hedgehog-glioma associated oncogene homolog 1 signaling enhances drug resistance in CD44(+)/Musashi-1(+) gastric cancer stem cells. Cancer Lett 369: 124-133, 2015.

52. Zhang L, Li L, Jiao M, Wu D, Wu K, Li X, Zhu G, Yang L, Wang X, Hsieh JT and He D: Genistein inhibits the stemness properties of prostate cancer cells through targeting hedgehog-Glil pathway. Cancer Lett 323: 48-57, 2012.

53. Ma D, Yu H, Xu S, Wang H, Zhang X, Ning T and Wu B: Stathmin inhibits proliferation and differentiation of dental pulp stem cells via sonic hedgehog/Gli. J Cell Mol Med 22: 3442-3451, 2018. 